\title{
Problematising Aboriginal nationalism
}

\author{
Julia Martínez
}

The modern concept of nationalism is a highly contested phenomenon. It provokes debate at both a theoretical and an emotional level. The idea of an Aboriginal nationalism is no less complex. This article discusses a range of perspectives on Aboriginal nationalism and relates them to theoretical debates. The works of Benedict Anderson and Anthony Smith are discussed in some detail. Both these theorists regard the nation as a 'modern' construct. They posit a range of conditions and processes which have enabled different peoples to generate a sense of nationalism. These models are advanced as useful tools for the ensuing discussion of Aboriginal nationalism and whether such a phenomenon exists or has ever existed in the modern sense. Their theories are necessarily problematic when viewed from a post-modern perspective which highlights the plural nature of identity, but the very gap between the 'modern' and the 'post-modern' allows us to historicise nationalism. Thus, the period of the 1960 s and 70 s sees the development of a 'modern' pan-Aboriginal nationalist, movement while in more recent years writers have highlighted the diversity of Aboriginal thought.

Any discussion of nationalism must begin with an attempt to define this elusive phenomenon. Benedict Anderson considers nationalism not as a political movement nor as a synonym for racism, but as a sense of patriotism or 'love of country'. He seeks the answer as to why 'modern' nations should 'command such profound emotional legitimacy'. The nation, he defines as 'an imagined political community' which is both 'inherently limited and sovereign'. The term 'imagined' refers to the way in which its citizens are able to conjure up a mental image of their nation. It does not imply that the nation is false or unreal, but rather, that it is an abstract concept. He describes the nation as a community because, 'regardless of the actual inequality and exploitation that may prevail in each, the nation is always conceived as a deep, horizontal comradeship'. ${ }^{2}$

According to Anderson, post-colonial nationalisms were not so much reactions against colonialism, as extensions of the colonising process. He argues that colonialism encouraged the spread of nationalism by introducing indigenous peoples to Western 'modernity' in the form of administration, education, increased mobility, and masscommunication. ${ }^{3}$ Modernity brought with it a new mode of apprehending the world, where notions of time and history were reshaped. The modern concept of history is 'an

1. Anderson 1983, p. 4.

2. ibid., p. 6.

3. ibid., p. 4. 
endless chain of cause and effect or of radical separations between past and present'. Modern time is marked by 'temporal coincidence, and measured by clock and calendar'. It was this reshaping of time which enabled individuals to conceive of their 'imagined community', allowing them to imagine the 'steady, anonymous, simultaneous activity' of all the other members of that community'. ${ }^{4}$ Anderson attributes this to the advent of mass-communication in vernacular languages made possible by print-capitalism and the dissemination of novels and newspapers. These forms of communication assumed a collective body of readers who share a common language and a common interest. In the minds of the readers, the national community became tangible. ${ }^{5}$

Western education played a key role in the development of nationalism outside Europe. It introduced indigenous peoples to the trappings of nationhood: 'common citizenships, popular sovereignty, national flags and anthems'.6 It also provided an indigenous intelligentsia with a knowledge of various models of revolution and alerted them to the growing international movement for universal self-determination. Colonial administrative systems instituted not only standardised education programmes but also, in cases such as Indonesia, introduced a new lingua franca, which made it possible for people from different language groups to communicate and so share their common experiences of colonialism. It was from this system that a young western-educated nationalist leadership emerged. ${ }^{7}$

Three colonial institutions which Anderson highlights as the building blocks of nationalism are: the census, the map, and the museum. The colonial census categorized the indigenous population, constructing identities that accorded with the preconceptions and administrative needs of the colonists. ${ }^{8}$ In Indonesia, for example, the Dutch tended to represent all 'Indonesians' as inlanders or natives, regardless of their ethnolinguistic background. ${ }^{9}$ The use of the colonial map as a logo for nationalists proved to be a powerful symbol of the nation, while colonial museums through their attempts to capture and study the indigenous culture, created a visual and written representation of 'native' cultural identity. ${ }^{10}$

Anderson's paradigm of post-colonial nationalism is problematic, however, as it suggests that a nationalism formed of heterogeneous peoples must necessarily be contrived and therefore without legitimacy. He does not allow that these nationalisms might engender emotional loyalty from the people or that indigenous peoples might reclaim the right to define their own cultural identity. It is here that Anthony Smith's contribution is useful, as it concentrates on the notion of ethnie, the 'collective cultural units' which make up nations. ${ }^{11}$ His definition of ethnie is sufficiently broad to encompass linguistically heterogeneous communities. He argues that ethnie need only be similar 'in those cultural traits in which they are dissimilar from nonmembers'. These traits may include food, music, and the arts or even simply pigmentation as in the case of

4. ibid., pp. 23-6.

5. ibid., p. 32 .

6. ibid., p. 81.

7. ibid., pp. 116-121.

8. ibid., pp. 164-5.

9. ibid., p. 122.

10. ibid., pp. 175-8.

11. Smith 1986, p. 13. 
Black Americans. ${ }^{12}$ Smith suggests that nationalism relies on the 'rediscovery and revitalization of ethnic ties and sentiments'. This, he argues, involves tracing kinship ties, popular mobilisation, the elevation of religion, language and customs and a rewriting of history to emphasise a unique collective past and destiny. ${ }^{13}$

These theories posited by Anderson and Smith provide a useful framework within which the development of 'modern' Aboriginal nationalism might be considered. Anderson points to the role of colonialism and the links between nationalism and modernity. In contrast, Smith takes the stance that post-colonial nationalisms rely on cultural or ethnic ties which engender emotional loyalty from their people. He asks us to consider the importance of kinship, language, and historic links with the land. In the case of Australia, Anderson's model appears relevant to the discussion of Aboriginal nationalism in the 1960s and 70s. The introduction of multiculturalism as a national policy proposed an alternative 'post-modern' form of the nation which did not rely on a single homogeneous culture or heritage. Stephen Castles, in discussing the legitimacy of the modern nation-state, argues that while the state has moved beyond national borders in response to demands of the global economy, in the face of homogenisation of world culture, cultural difference has become increasingly valued as each ethnic group seeks to reestablish their cultural heritage. ${ }^{14}$ This shift in emphasis has ramifications for the Aboriginal peoples in Australia in that it has legitimised the concept of nations within a nation and provided a less restrictive model for debate.

This paper now turns to discuss the development of Aboriginal nationalism and exploring these theoretical frameworks. As a non-indigenous Australian I have relied upon the writings of various Aboriginal activists and writers to understand the various positions and perspectives on nationalism. The complexity of this subject undoubtedly renders it beyond the scope of any single article. My limited aim is to consider both 'modern' and 'post-modern' forms of Aboriginal nationalism in twentieth century Australia. The term pan-Aboriginal is used to refer to a 'modern' sense of the nation, in that it is conceived of as an Australia-wide phenomenon. This is contrasted with the idea of 'traditional' lands as the basis for the individual Aboriginal nations and the sense of community attachment which is demonstrated by those who identity themselves with their people; Nyungars, Nangas, Yolngus, Kooris, Murris and others. ${ }^{15}$

Early notions of nationhood suggested that the nation was based on the common heritage of a people. In this sense, prior to colonisation there was no Aboriginal nation as the Aborigines did not comprise an homogeneous group. There were some 500 'separate traditional communities', each speaking their own language or dialect. ${ }^{16}$ Customs differed from region to region, accentuated by the diverse ecologies of the Australian continent. Rather, one might argue, there were many small Aboriginal nations. Aranda men in the 1930s emphasised the distinct territorial divisions between peoples, explaining: 'Our fathers taught us to love our own country, and not to lust after the lands belonging to other men'. ${ }^{17}$ The kinship system which ordered relationships within

12. ibid., p. 26.

13. ibid., p. 145.

14. Castles, et al. 1990, pp. 188, 140.

15. Mudrooroo 1995, p. v.

16. Reynolds 1987, p. 8. 
'tribal' groupings strengthened the sense that those in other 'tribal' groups were 'outsiders'. In this sense, there was no pre-existing pan-Aboriginal nation and no common history on which to base a sense of nationalism. According to modernists, however, this 'construction' of nationalism, is common to all nationalisms, including those of Europe which were created by the suppression of regional differences, dialects and cultures. ${ }^{18}$

The development of a pan-Aboriginal nation can be expressed in terms of the colonial model presented by Anderson, which suggests that the common experience of colonisation provided the catalyst for the development of a pan-Aboriginal identity. ${ }^{19}$ When the British arrived in 1788, Australia was judged to be 'terra nullius' and the Aboriginal people were not acknowledged as the owners of their tribal land. ${ }^{20}$ Whilst they were nominally accepted as British subjects, they were not initially considered as a potential workforce, as was the case in most other colonies. Anderson assumes that colonisation brings the trappings of a modern European culture to at least a portion of the indigenous population, but this was not initially the case in Australia. In the 1937 federal conference on Aboriginal policy it was decided that the destiny of Aborigines was 'their ultimate absorption by the people of the Commonwealth' but this official statement of assimilation was nevertheless based on a narrow and limited form of citizenship for those of Aboriginal descent. ${ }^{21}$

Before that time, it was assumed that the Aboriginal people would simply die out and that it was the duty of the state governments to 'smooth the dying pillow.' Aborigines were to be 'protected', which in practice resulted in their losing all personal freedom. Ironically, it was the harshest aspects of this policy which produced the first seeds of nationalism. In keeping with the White Australia policy, it enshrined the principle of racism which gave the Aborigines no choice but to consider themselves as a 'race apart'. 'Full-blood' Aborigines were segregated from white society and deprived of their civil rights. Their culture was threatened by institutionalisation and an insistence on Christian values and codes of conduct. As Bain Attwood commented, 'the more consistently and rigorously authoritarian and oppressive colonial racial policy and practice has been, the more the conditions for a common Aboriginal identity have grown'.22

Colonial oppression, however, according to Anderson, is not sufficient to account for the development of nationalism. It required the tools of modernity: common language to facilitate communication; the education of an intelligentsia to lead the nationalist movement; and a means of mass-communication to allow the community to experience a sense of simultaneity and uniform purpose. In Australia, the first of these conditions was achieved gradually, as more and more Aborigines came to use English as their lingua franca, taught, in many cases in mission schools. This enabled Aborigines from different language groups to communicate with each other. As for the other conditions, one might argue that they were not fulfilled until the 1960 s. The education of an

17. Broome 1994, p. 14.

18. Hutchinson 1994, p. 4.

19. Broome 1994, p. 17.

20. Reynolds 1987, p. 12.

21. Broome 1994, p. 161.

22. Attwood 1989, p. 150. 
Aboriginal intelligentsia was linked with the government policy which dictated that 'half-caste' children be separated from their parents and sent away to be raised and integrated into white society. One outcome of this policy was the presence in the $1960 \mathrm{~s}$ and 70s of a substantial group of western-educated nationalists.

Tracing the education of Charles Perkins, for example, demonstrates the link between 'colonial' administrative policies and the creation of an Aboriginal intelligentsia. At the age of nine, in 1945, he was taken from Alice Springs to Adelaide where he was raised in a white, Christian, middle-class atmosphere. His life there, according to Peter Read, 'imbued in him a faith in pan-Aboriginalism not shared by his community at the time'. Read notes that '[m]any of today's national and community leaders share Perkin's background of cultural dislocation at an early age'. ${ }^{23}$ From Adelaide, Perkins moved on to Sydney where he completed a Bachelor of Arts at the University of Sydney. His educational pilgrimage eventually led him to the capital, Canberra and the Department of Aboriginal Affairs. Charles Perkins' sense of Aboriginal nationalism resulted from his experience of the modern Australian educational and administrative system. This gave him a view of Aborigines that was national rather than regional. Other Aborigines who could similarly be regarded as the vanguard of Aboriginal nationalism include Paul Coe, Michael Anderson, and Kevin Gilbert.

Gilbert discusses the emergence of an Aboriginal intelligentsia in his book Because a White Man'll Never Do It, published in 1973. He quotes Wootten of the Aboriginal Legal Service as saying:

There is now a new breed of Aboriginal-the angry, articulate young men and women, proud of their Aboriginality, deeply concerned for their people all over Australia...determined to demand justice now...They alone have the enthusiasm, the courage and the eloquence to overcome the apathy and selfishness of white Australians and to unite their own people all over Australian a great forward movement. ${ }^{24}$

This group of Aborigines most closely corresponds to Anderson's notion of a radical young nationalist intelligentsia. Where the Australian experience differs from other continents, is in the degree of acceptance of this pan-Aboriginal message. Perkins acknowledged that his views were not accepted by his home community. During the 1960 s and 70s, however, there was a tendency to attribute this resistance to a lack of communication, or a failure on the part of Aboriginal communities to take on the lessons of modern education, rather than the inadequacy of the nationalist model.

With Aborigines spread out over Australia's vast area, any form of pan-Aboriginal communication was impossible without modern technology. Even so, communication with remote Aboriginal groups remains difficult. Anderson's discussion of mass-communication and the dissemination of ideas via printed material assumes a high level of literacy and access to printed materials. During the 1970s, however, when the nationalists were engaged in promoting their movement, these avenues of communication did not exist in rural Australia. Gilbert, describing the situation in the 1970s wrote:

23. Read 1990 , pp. xiii-xiv.

24. Wootten in Gilbert 1973, p. 130. 
Very few blacks read regularly and consistently, even about their own movement. One reason is that not a few are illiterate. It is this group whom Bobbi Sykes tried to reach and alert about the Embassy when she did her trip through the Northern Territory last year. Others, particularly the reserve and slum-dwelling blacks of the south, can read because schooling was enforced. But many have never become adept enough at it to enjoy it and the content of an average newspaper is of no interest anyway, because none of it has any apparent bearing on their lives... Only television has managed to crack this situation a little bit... ${ }^{25}$

He suggests that the spread of communications via the television will have a positive effect on their movement. Again, the idea is raised that their cause was not necessarily perceived as having 'any apparent bearing' on the lives of Aborigines as it fell outside the scope of local concerns. Jeremy Beckett discussed this issue in relation to the election of a New South Wales state representative for the Welfare Board. He commented that: 'it has never been possible to find a candidate known to everyone. The only one whose name is remembered and occasionally mentioned, Bill Ferguson, was related by marriage through his brother to the Carowra Tank people'. ${ }^{26}$ This suggests that the kinship system which gives cohesion to Aboriginal communities could be used to strengthen the case for a national 'imagined community'.

Viewed from a post-modern perspective, this reluctance of some sectors of the Aboriginal population to embrace nationalism corresponds with the general questioning of nationalism in its modern form. While Anderson claims that an intelligentsia spread the ideology of nationalism, there is evidence that some Aborigines were not inclined to be led by intellectuals. Furthermore, other Aboriginal intellectuals, such as Pat $\mathrm{O}^{\prime}$ Shane, have criticised this form of nationalism.

One reason for the ambivalent position of Aboriginal intellectuals was the perception that they had cast their lot with the 'whites' and that their work is led by 'whites'. In the early stages of its development, the Aboriginal intelligentsia was aided by various white organisations which sought to advance the Aboriginal cause. The role of the church was crucial in providing an Australia-wide network of support. ${ }^{27}$ Similarly, Communists such as Donald McLeod, and Frank Hardy worked with Aborigines, encouraging them to unite in protest against the government. Using Marxist rhetoric, Hardy claimed: 'While black men are in chains, no white men can be free' ${ }^{28}$ These 'white' activists tended to regard the Aborigines as one people, as 'black' thus giving strength to a concept of Aboriginal nationalism based on colour.

Aboriginal activists of the 1930 s promoted not so much a separate Aboriginal nationalism as the inclusion of Aborigines within the Australian nation. William Ferguson, for example, the president of the Aborigines Progressive Association, wrote in 1940 to the Governor-General, pleading for full citizenship for Aborigines. He wrote: 'we do not expect wild Aborigines living in the remote part of Australia to be made citizens'. ${ }^{29}$ Ferguson appears to be advocating a form of citizenship based on 'civilisation'. This is

25. Gilbert 1973, p. 111.

26. Beckett 1988b, p. 134

27. Franklin 1976, p. 137.

28. Hardy 1968, p. 49.

29. Ferguson in Franklin 1976, pp. 151-2. 
not to suggest that he regarded the exclusion of 'tribal' Aborigines as permanent. While in 1938, anthropologist Dr Donald Thomson was arguing for 'inviolable reserves of tribal lands' in order to prevent further 'detribalisation', Ferguson and Jack Patten were arguing that 'uncivilised blacks' were 'willing and eager to learn when given a chance'. ${ }^{30}$ Nevertheless, they were conforming to the criteria of citizenship imposed by the Australian nation rather than seeking to promote a separate Aboriginal nationalism. The criticism they expressed in the manifesto 'Aborigines Claim Citizen Rights!' reveals their anger at the treatment of Aborigines under the so-called Protection system, but focuses on the potential for improvement in the Australian nation. They ask that Aborigines be allowed to claim 'ordinary citizen rights' ${ }^{31}$ As the organisers of the 1938 Day of Mourning \& Protest, they wrote representing 'The Aborigines of Australia' appealing to the:

Australian Nation of today to make new laws for the education and care of Aborigines, and we ask for a new policy which will raise our people to FULL CITIZEN STATUS and EQUALITY WITHIN THE COMMUNITY. ${ }^{32}$

By the 1960s, however, there emerged a group of Aboriginal activists who were more anti-colonial in their outlook. Following Anderson's model, they took their inspiration from overseas examples. In particular, Black Americans such as Malcolm $X$ and Martin Luther King provided role models. The American Black Panther Party which began in 1966 with a message of militant 'Black Power' inspired some Aborigines to follow their lead. An Australian Black Panther Party was formed in 1972 in Brisbane. ${ }^{33}$ They copied the Marxist-Leninist rhetoric and like their American counterparts made demands for: "and, bread, housing, education, clothing, justice and peace' ${ }^{34}$ Aboriginal activists such as Gary Foley and Paul Coe showed that like the Americans they had considered the use of more aggressive tactics. Paul Coe said:

To me, the idea that the Aboriginal people will one day pick up the gun, to use it perhaps, to build their own separate state or find some other way of ensuring that the race does survive, is a just one. It's something that I'm not frightened of because it is something that's just got to happen. ${ }^{35}$

Many were frightened by such a concept and it would be wrong to suggest, that all Aborigines were influenced by the 'Black Power' movement. Ted Fields wrote: 'We Aborigines do not identify with the colour black. Our identity is based on a much deeper spiritual awareness of ourselves as a people'. Evonne Goolagong, he noted, does not identify herself as black: 'She identifies as Aboriginal, which is more national and specific' ${ }^{36}$ These contrasting views demonstrate the nationalist push for 'state' power on the one hand, and the search for a spiritual, or emotional sense of 'imagined community' on the other.

30. Horner 1974, pp. 56-58.

31. Ferguson cited in Horner 1974, p. 59.

32. Horner 1974, p. 199.

33. Franklin 1976, p. 207.

34. Marable 1984, p. 122.

35. Cited in Gilbert 1973, pp. 105-6.

36. Cited in Harris 1972, p. 103. 
The student Freedom Rides of the early sixties similarly were, in part, inspired by the Black American model. They were, according to Charles Perkins, a response to the press coverage of the American civil rights movement. Many students were cautious in their approach to the tour, however, as nobody wished 'to be seen aping American students'. Nevertheless, in a letter describing the proposed tour, Perkins chose to enclose a pamphlet written by Martin Luther King which expressed his method of 'non-violent direct action'. ${ }^{37}$ Unlike the American Freedom Rides however, those in Australia were dominated by white protesters. ${ }^{38}$ Chicka Dixon commented that:

Looking back on the movement, from the time we went on the 1966 Freedom Rides...things have changed tremendously. In those days you could only get two blacks involved-me and Charlie Perkins-with a lot of white students on a bus. Today when you ask blacks to move on a certain issue, you can get a heap of them. 39

A decade later, in 1972, the Aboriginal movement demonstrated its desire for independence with the Aboriginal 'Tent Embassy' which was erected on the lawns of Parliament House in Canberra. The group of 'nationalists' appointed a High Commissioner, Michael Anderson, and flew an Aboriginal flag of green, red and black. The green symbolised the land, the red, bloodshed, and the black stood for the Aboriginal people. ${ }^{40}$ The use of symbols such as the flag, the protesters suggested the possibility of creating an Aboriginal nation, with all the official trappings of other modern nation states. This differed conceptually from the 1938 vision of Aborigines as citizens of Australia.

The Embassy's central demand was for land rights. Their protest took its inspiration from indigenous peoples throughout the world who had fought for land rights. Using the medium of television, their cause was able to gain support from Aborigines all over Australia. The demonstration had a broad appeal and was supported by conservatives such as Sir Douglas Nicholls, Australia's first Aboriginal knight, who visited the 'Embassy' to show his approval of their work. ${ }^{41}$ This unity suggests an emerging pan-Aboriginal feeling in the 1970s. As Chicka Dixon declared: 'As long as I breathe I'm black... of course we down south haven't got our culture, we haven't got our language, but we have the feeling that we belong...we're black Australians' ${ }^{42}$ At the time, some suggested that the 'Embassy' was simply evidence of Communist interference, but Gilbert confirmed that, '[f]rom its inception to its demise, the Aboriginal Embassy was a totally Aboriginal thing' ${ }^{43}$

While some Aboriginal intellectuals might have accepted western models of nationalism, other saw this as a betrayal of the spirit of Aboriginal culture. Pat O'Shane, in discussing the proposed treaty between the Aborigines and the Australian government, said that:

37. Read 1990, p. 100.

38. Franklin 1976, pp. 102-3.

39. Cited in Gilbert 1973, p. 32.

40. Franklin 1976, p. 210.

41. ibid

42. Cited in Broome 1994, p. 184.

43. Gilbert 1973, p. 28. 
...the proponents of the issue...loudly and persistently proclaim the Aboriginal nation. To be honest, I don't know what constitutes a nation, but my understanding is that a nation is defined by territory and some form of central government. ${ }^{44}$ This concept, she argued 'is entirely alien to Aborigines' ${ }^{45} \mathrm{Her}$ criticism has been taken up by others who have sought to reconceptualise the Aboriginal nation in a way which might allow for the diversity and plurality of the Aboriginal peoples.

Another criticism of the nationalist model was that is did not take sufficient account of the contrast between the Aboriginal practice of 'finding the common mind of the group as against the self-assertion of individualistic European leadership' ${ }^{46}$ This issue was considered by Gilbert who wrote:

Aborigines have not taken kindly to those in their midst who have assumed to be 'leaders'. A strong reason is a uniquely Aboriginal individualism which does not accept the right of anyone to speak for them without long and exhausting prior consultation. ${ }^{47}$

These arguments, however, assume that Aboriginal nationalism must define itself in terms of its 'traditional' culture in order to be considered legitimate. A modern phenomenon of Aboriginal nationalism, however, did not need to be 'traditional' in order to inspire a sense of love and loyalty from its followers.

Anderson argues that in terms of creating a new national culture, one must take into account the influence of colonial structures. His discussion of the colonial map, census and museum can be applied to the case of Australia. Aboriginal nationalists did take the colonial map of Australia as defining the boundaries of their nation. This was in contrast to the many Aborigines who identity themselves according to their own "traditional' land. Vincent Lingiari, for example, said: 'My people are Gurindji, who live in Wave Hill area. That me countr". 48 This can be contrasted with the words of Coral Edwards, co-ordinator of Link-Up, who said:

Aboriginality means to me that you come from the land. It's your land, Australia, the trees, the grass, the seas, the deserts, the rainforests, are all linked with yourself. It's something nobody can take away from you. ${ }^{49}$

This definition of the land has expanded the Aboriginal territory to encompass the whole of Australia. Instead of relating to one specific area, the nationalist identifies with everything from deserts to rainforests. This image of the Aboriginal nation comes from the representations of Australia produced by the television and the tourist industry. Ironically, these images have been produced as part of an effort to encourage Australian nationalism in general, and as such have become the 'imaginings' of multi-cultural Australia.

British attempts to create a census of Aborigines, 'saw Aborigines wherever they were as being all the same, and the various clans, groups, tribes, and communities experienced colonisation in very similar ways' ${ }^{50}$ Early twentieth-century categorisations

44. O'Shane 1991, p. 154.

45. ibid.

46. Harris 1972, p. 109.

47. Gilbert 1973, p. 139.

48. Cited in Hardy 1968, p. 71.

49. Bowden \& Bunbury 1990, p. 17. 
tended to define Aborigines purely in terms of race. They were either 'half-castes' or 'full-bloods', terms which carried connotations of 'semi-civilised' or 'primitive'. It was not until the 1960s that the Commonwealth government decided against making 'distinctions among people of Aboriginal descent, opting instead for self-identification and/or recognition by a community' ${ }^{51}$ The choice remained, however, between Aboriginal and non-Aboriginal, implying an acceptance by the state of a national Aboriginal identity. Despite this, the choice for many Aborigines was to designate 'their people' as those belonging to their clan or local community.

Anderson's argument that the colonial museum attempted to capture the 'essence' of the 'traditional' culture is similarly true of Australia. Australian writers have portrayed the Aborigine as part of Australia, the 'timeless land'. Desert Aborigines have become a national emblem, 'represented as black, male, bearded and scantily dressed, holding a spear and with his eyes fixed on some distant object-all against a background of scenic splendour' ${ }^{52}$ European representations of Aboriginal culture have tended to concentrate on the image of the noble savage. Aboriginal artifacts such as the boomerang have become items for sale by the tourist industry, along with performances of corroborrees and 'bush tucker' restaurants. This issue has recently become an important focus for Aboriginal activists who have reclaimed the right to define their own identity, to write their own history and to resume custody of their culture. ${ }^{53}$

Another important aspect of nationalism is the role of language. According to Anderson, the language of the colonial administration allowed heterogeneous peoples to develop a common language. The use of English as the lingua franca by Aborigines has provided the means for communication across Australia. In some cases urban Aborigines who use English as their first language have adapted the language to suit their own needs. In Adelaide, for example, 'the Lingo', which is made up of a limited number of Aboriginal words and phrases interwoven with English, serves as a symbol of Aboriginal identity. ${ }^{54}$ On the other hand, those who are attempting to regain their community ties, have been supported by institutions such as the Central Australian Aboriginal Media Association (CAAMA) which broadcasts in Aboriginal languages to the people of Central Australia. One Aborigine commented: 'there is no doubt that hearing your own language on radio and television contributes to a sense of identity and pride' ${ }^{55}$ Another explained: 'You have to know your language because you'll never be able to learn your Dreaming and if you don't know your Dreaming you can't identify where you belong'. ${ }^{56}$ While this sense of identity emphasizes the tribal over the national, the promotion of languages such as Pitjatjanjara and Warlpiri need not work against a sense of pan-Aboriginality. ${ }^{57} \mathrm{~A}$ post-modern understanding of nationalism would suggest that there is no need to eliminate cultural diversity in order to achieve a sense of nationalism. This form of pan-Aboriginal nationalism is expressed by

50. O'Shane 1991, p. 148.

51. Beckett 1988a, p. 207.

52. ibid., pp. 205-6.

53. Pam Johnston in Langford Ginibi 1994, p. 49.

54. Beckett 1988b, p. 83.

55. Bowden \& Bunbury 1990, p. 29.

56. ibid., pp. 32-3.

57. ibid., p. 35. 
Mudrooroo who wrote: Us Mob are many mobs, but we all come from that great tree which is Australia'. ${ }^{58}$

The importance of land is a theme which recurs in all discussions of nationalism. A 'love of country' can be operate simultaneously at both a continent-wide phenomenon and in a more local sense. Smith writes: 'nations need homelands... historic territories in which 'our ancestors' lived and which we carry in our hearts'. ${ }^{59}$ In the case of pan-Aboriginal nationalism this is particularly apt. While individual communities have laid claim to their traditional lands, the issue of Land Rights has been a unifying force precisely because land is a symbol which carries meaning for all indigenous Australians. Patriotism is often expressed in terms of being "of the lan". This sentiment was conveyed by Banjo Woorunmurra who declared: 'We don't want money, we want our land. Our spirits are in our land. Our old people are still in the land, our motherland, our dusty old land'. ${ }^{60}$

According to Smith, another factor which engenders a sense of national pride is the writing of nationalist histories and the creation of national heroes. Aborigines today are forging their own history to create a new nationalist identity. For example, Aboriginal writer, Mary Coe published a rewriting of Australian history in 1986 which presented the Aboriginal people as agents who resisted colonial oppression. 'The final images in the text are of a land rights demonstration and the Aboriginal flag emblazoning the back cover-"we have survived as a nation". 61 Smith argues that writing about a 'golden age assures each generation of its distinctive heritage against the assimilative pressures and temptations of modernity, which might otherwise swamp them.' ${ }^{62}$ Rejecting the modernist notion of artificially contrived nationalism, he argues that: 'Traditions, myths, history and symbols must all grow out of the existing, living memories and beliefs of the people who are to compose the nation'. ${ }^{63}$ The development of Aboriginal oral history in a written format has helped to transmit to a wider audience histories composed of myths and memories. ${ }^{64}$ This is particularly true of the 1990 s, but even in the 1960 s there was a move to regain a knowledge of 'tribal custom and belief' in the face of cultural assimilation. ${ }^{65}$

It is difficult to discuss forms of nationalism without placing them in the context of the state. The nation-state of Australia remains dominated by non-indigenous, colonial structures. Attempts to establish some degree of economic or political self-determination have been largely unsatisfactory. The consequences of thinking nationally rather than locally has been most severely criticized in discussions of the role of ATSIC. Papers published by the Council for Aboriginal Reconciliation in 1994 emphasised the need for a decentralisation of funding with community-based organisations effectively bypassing ATSIC. This leaves open the question of what form a centralised Aboriginal state

58. Mudrooroo 1995, p. vi.

59. Smith 1986, p. 213.

60. Broome 1994, p. 196.

61. Ariss 1988, p. 137.

62. Smith 1986, p. 213.

63. Smith 1991, pp. 358-9.

64. Barwick 1988, p. 32.

65. Gilbert 1973, p. 131. 
might take. Michael Mansell argued that the 'best way to provide the power for Aboriginal self-government is to build that right into the Australian Constitution... ${ }^{66}$ These sentiments have been echoed in the 1998 Convention which considered the new constitution for an Australian Republic. ${ }^{67}$ Mansell describes a framework for 'self-government' in which:

There may be any number of Aboriginal communities in Australia operating a form of self-management process in their own territories under the broad political umbrella of the Australian nation. ${ }^{68}$

Nevertheless, he puts this forward as a compromise and voices the hope that one day these communities might come under the umbrella of an Aboriginal nation.

Writing in 1995, Mudrooroo argues for a shift of focus for political power from the national to the community level, stating: '... if Us Mobs want to establish an Indigenality from the grass roots up, we must use the extended family as its political foundation'. ${ }^{69}$ Smith gives a similar argument for nationalism in his critique of Anderson. $\mathrm{He}$ focuses on 'not only patterns of family...but also the values, symbols, myths and memories that are transmitted through these channels' ${ }^{70}$ Aboriginal values are inextricably linked to the family and the memories that are passed on from one generation to the next. Much of the revival of Aboriginal culture relies on a this process. Hetti Perkins, mother of Charles Perkins, for example, saw the beginning of a 'massive Aboriginal revival of self-confidence and willingly filled the role of traditional granny and aunty $^{\prime} .^{71}$ Through the family Aborigines can gain a sense of the unique ethos of their culture which centres on 'tolerance, compassion, humour, and the emotional warmth of personal relationships'. ${ }^{72}$ Taking account of the importance of family, H. C. Coombs has argued that a new model of self-government for Aborigines should not be determined in advance, 'but should emerge slowly from local meetings all over the country' ${ }^{73}$ It is worth noting the difference between this method of communication and the 'modern' means of communication cited by Anderson as necessary to nationalism.

In Ruby Langford Ginibi's book about her Bundjalung people, the Koori people are divided into three types: 'traditional tribal people, the mission bred ones... and the urban Koori'. Langford Ginibi emphasises however, that they are 'all one mob'. ${ }^{74}$ She writes: 'In our Koori way, we all want to go back to where we came from originally, it is like a magnet that keeps drawing us to the places where we were born to find our extended families'. ${ }^{75}$ The importance of place and family indicates an 'imagined community' based on clan connections. Nevertheless, her book also acknowledges the presence of other Aboriginal nations and gives a sense of common cause, which allows us to conceive of a federation of Aboriginal nations. Langford Ginibi's adopted daughter

66. Council for Aboriginal Reconciliation 1994a, p. 29.

67. See also Council for Aboriginal Reconciliation 1994b, p. 7.

68. Council for Aboriginal Reconciliation 1994a, p. 29.

69. Mudrooroo 1995, p. 31.

70. Smith 1990, p. 18.

71. Read 1990, p. 6.

72. Barwick 1988, p. 27.

73. Coombs cited in Reynolds 1996, p. 147.

74. Pam Johnston cited in Langford Ginibi 1994, p. xi.

75. Langford Gínibi 1994, p. 1. 
Pam Johnston is one of the Gamilerori people. She describes the Bundjalung as but one of Aboriginal Australia's many nations. Nevertheless, her involvement in the book adds to the sense of Aboriginal 'inter-national' cooperation. ${ }^{76}$

Another aspect of nationalism highlighted by Smith is the need for national heroes. ${ }^{77}$ Aboriginal heroes who have appeared on television and so into the homes of Aborigines, include writers such as Kath Walker, the dancers of Aboriginal Islander Dance Theatre, the painter Namatjira, and the actor Ernie Dingo. Sporting heroes have similarly played an important role in promoting Aboriginal national pride. There are numerous examples of footballers, boxers and Olympic athletes. The most recent of these, Cathy Freeman, demonstrated her power as an Aboriginal national hero when she ran the victory lap at the 1994 Commonwealth games holding not only the Australian flag, but the Aboriginal flag, the symbol of the Aboriginal nation. The flag which combines red for the land, black for the people and yellow for the sun, the symbol of life, sent a message to all Australians and Aborigines in what was perhaps the most persuasive experience of simultaneity to date. At that moment, the Aboriginal imagined community' was a reality, conveyed instantaneously using the technology of satellite into the minds of each Aboriginal. ${ }^{78}$

Mandawuy Yunupingu, lead singer and song-writer of the band Yothu Yindi, unlike early nationalists who were dislocated from their traditional lands and culture, combines a sense of nationalism with a deep attachment to his own land and clan ties. He takes his sense of Aboriginality from the traditions of his people, the Yolngu, in Arnhem Land. Though Yothu Yindi serves as a symbol for Aborigines across Australia, Mandawuy describes the band as a 'contemporary voice for us Yolngu'. The name itself refers to the kinship system of the Yirritja and Dhuwa people, who together make up the Yolngu. ${ }^{79}$ Mandawuy was educated as a Yolgnu but was also taught English in a mission school. Today, he is principal of the local school which teaches both 'authentic Yolngu schooling' and the standard Australian curriculum. ${ }^{80}$ For Mandawuy, his immediate community is the Yolgnu, however he also has a national vision which is wider than pan-Aboriginality. He believes that:

Together in the twenty-first century we can construct a unique way of life here, inspired by the traditions of Aboriginal Australia and of Europe and Asia. Land rights for Aboriginal Australians are in the best interests of all Australians. Land rights must respect the contributions made by those people who have immigrated here over the past two hundred years, as well as recognising the place of those who have always belonged to this land. 81

Nationalism for Mandawuy is not about loyalty to one group, one culture, but is manifested in three distinct but connected layers: loyalty to clan, to pan-Aboriginality, and finally, to a truly multicultural Australia.

76. Pam Johnston cited in Langford Ginibi 1994, p. xi

77. Smith 1986, p. 213.

78. Brennan 1995, p. 184.

79. Yunupingu 1994, p. 1.

80. ibid., pp. 4-5.

81. ibid., p. 11. 
The relationship between the 'Aboriginal nation' in whatever form it might take, and the Australian state is one which has yet to be reconciled. The literature produced by the Council for Aboriginal Reconciliation in 1994 focuses on the sharing of Aboriginal culture with non-indigenous Australians. By promoting the diversity of indigenous cultures and the richness is their heritage they envisage a 'genuine celebration' of Australia's cultural diversity. ${ }^{82}$ This theme was taken up at the 1998 Convention to discuss the formation of an Australian Republic. The Council imagined that this historical event might provide the forum for reconceptualising the Australian nation-state in such as way give a central place to indigenous Australians. ${ }^{83}$

This paper has shown that Aboriginal nationalism and the Aboriginal nation have been conceptualised in many forms by Aboriginal groups. The theories of Anderson and Smith provide us with a means of analysing the phenomenon of 'modern' panAboriginal nationalism as it appeared in the 1960 s and 70 s. In addition, by considering the tension between their theoretical models and the range of Aboriginal attitudes, this paper uncovers a counter-movement which regards the modern nation as inappropriate as an expression of Aboriginal 'love of country'. In keeping with a 'post-modern' version of the nation, new models of Aboriginal nationalism emphasise loyalty to clan, to family and this relects the many Aboriginal nations. Nationalism as a pan-Aboriginal phenomenon has not been replaced by this model so much as enriched by it. The notion of a federation of Aboriginal nations; each with its own sense of community, ensures a stronger base on which to found a national 'imagined community'.

\section{References}

Anderson, Benedict 1983, Imagined Communities: Reflections on the origins and spread of Nationalism, London.

Ariss, Robert 1988, 'Writing Black: the construction of an Aboriginal discourse' in Past and Present: The Construction of Aboriginality, ed. J. Beckett, Canberra, pp. 131-146.

Attwood, Bain 1989, The Making of the Aborigines, Sydney.

Barwick, Diane 1988, 'Aborigines of Victoria' in Being Black: Aboriginal Cultures in 'Settled' Australia, ed. I. Keen, Canberra, pp. 27-32.

Beckett, Jeremy 1988a,'The past in the present; the present in the past: constructing a national Aboriginality' in Past and Present: The Construction of Aboriginality, ed. J. Beckett, Canberra, pp. 191-212.

1988b, 'Kinship, mobility and community in rural New South Wales' in Being Black: Aboriginal Cultures in 'Settled' Australia, ed. I. Keen, Canberra, pp. 117-136.

Birch, Anthony, H. 1989, Nationalism and National Integration, London.

Bowden, R \& Bunbury, B. 1990, Being Aboriginal, Sydney.

Brennan, Frank 1995, One Land, One Nation, St. Lucia.

Broome, Richard 1994, Aboriginal Australians: Black Responses to White Dominance, 17881994, 2nd Edition, North Sydney.

Castles, Stephen et al. 1990, Mistaken Identity: Multiculturalism and the Demise of Nationalism in Australia, Leichhardt.

82. Council for Aboriginal Reconciliation 1994b, p. 5.

83. ibid. , p. 7 . 
Council for Aboriginal Reconciliation 1994a, Controlling Destinies: Greater Opportunities for Indigenous Australians to Controlt heir Destinies, Canberra.

—1994b,Valuing Cultures: Recognising Indigenous Cultures as a Valued Part of Australian Heritage, Canberra.

Fletcher, Christine 1992, Aboriginal Politics: Intergovernmental Relations, Carlton.

Franklin, Margaret, A. 1976, Black and White Australians, South Yarra.

Gellner, Ernest 1983, Nations and Nationalism, Oxford.

Gilbert, Kevin J. 1973, Because a White Man'll never do it, Sydney.

Hardy, Frank 1968, The Unlucky Australians, Melbourne.

Harris, Stewart 1972, This Our Land, Canberra.

Horner, Jack 1974, Vote Ferguson for Aboriginal Freedom, Sydney.

Hutchinson, John 1994, Modern Nationalism, London.

Langford Ginibi, Ruby 1994, My Bundjalung People, St Lucia.

Marable, Manning 1984, Race, Reform and Rebellion: The Second Reconstruction in Black America, London.

Mudrooroo 1995, Us Mob, History Culture, Struggle: An Introduction to Indigenous Australia, Sydney.

O'Shane, Pat 1991, 'A Treaty for Australians' in Sovereignty and Indigenous

Rights, ed. William Renwick, Wellington, pp. 147-155.

Read, Peter 1990, Charles Perkins: A Biography , Ringwood.

Reynolds, Henry 1987, The Law of the Land, Ringwood.

-1996, Aboriginal Sovereignty: Reflections on Race, State and Nation, St Leonards.

Rowley, C.D. 1986, Recovery: The Politics of Aboriginal Reform, Ringwood.

Rowley, C.D. 1970, The Destruction of Aboriginal Society, Canberra.

Smith, Anthony, D. 1979, Nationalism in the Twentieth Century, Canberra.

-1986, The Ethnic Origins of Nations, Oxford.

-1990, 'The supersession of nationalism?' International Journal of Comparative Sociology, XXXI, 1-2.

-1991, 'The nation: invented, imagined, reconstructed?' Millenium: Journal of International Studies, Vol. 20, No.3, pp.353-368.

Yunupingu, Mandawuy 1994, 'Yothu Yindi-finding balance' in Boyer Lectures, Voices from the Land, Sydney, pp.1-11. 